\title{
音響による食品物性評価法
}

\author{
西 津 貴 久 \\ 岐阜大学応用生物科学部応用生命科学課程
}

\section{Acoustic Methods for Characterizing Physical Properties of Food Products}

\author{
Takahisa NISHIZU \\ Department of Applied Life Science, Faculty of Applied Biological Sciences, Gifu University, \\ 1-1 Yanagido, Gifu 501-1193, Japan
}

\begin{abstract}
We found that the change with time of milk curd strength during the process of lactic acid fermentation and the change with time of freezing rate during the freezing process of food material can be monitored by measuring ultrasonic velocity. While the ultrasonic velocities of fruits and vegetables depend on not the "hardness" but the gas volume fractions of their tissues, the propagation velocities of impact vibration have strong correlations with their elastic properties. We have developed a measurement system for volume/density of food material by using phenomena of Helmholtz acoustic resonance. We found that the Helmholtz resonant frequency for food material having a pore structure is lower than that of non-porous food material having the same volume. Based on the theoretical consideration on the relations between the physical properties of porous food and the reduction of resonant frequency, we have also developed a measurement system for evaluating beer foam characteristics and bread texture. In another study we have found that the frequency of crack vibrations generated during chewing deep-fried foods has a close correlation with the results of sensory evaluation of their crispness.
\end{abstract}

Keywords: ultrasonic velocity, Helmholtz resonance, chewing vibration, texture property of porous food material

1. 緒言

食品の物性, 中でもテクスチャー特性の多くは, 力, 変位, 速度, 加速度などを対象物に与えたときの応答 (反 力・変位など）を記述するためのパラメータとして定 義される．例えば，粘弾性パラメータの測定に標準的 に用いられているテクスチャーアナライザ，クリープ メータ，レオメータ，DMAなどは，この特性量の定義 に沿った測定を実現することができる。しかし，これ らの手法はいずれも，試料を破壊して（あるいは破壊 しながら）測定するため，測定中の組織構造の破壊が 物性值に影響を及ぼす可能性がないとはいえない。ま たプロセス中の物性変化を捉えることは困難である. これらの問題を回避する手段の 1 つとして，音響エネ ルギーを入力し，元の応答を音響信号として捉える一 連の測定法がある。これは，材料を破壊や塑性変形さ

(受付 2020 年 5 月 8 日，受理 2020 年 5 月 30 日)

テ501-1193 岐阜県岐皁市柳戸 $1-1$

$\dagger$ Fax: 058-293-2888, E-mail: nishizu@gifu-u.ac.jp
せることなく対象の粘弾性を把握する手段として有効 である，一方，音響エネルギーを入力するのではなく， 咀嚼音のように，食品構造を破壊したときの応答を音 として捉える方法も音響を利用した測定法ということ ができる [1].

音響を利用した物性測定は工業材料では一般的であ り，理論や測定法もすでに確立されている。しかし対 象を食品とした場合，その多成分からなる不均質な構 造ゆえに，従来の測定法の適用や得られたデータの解 釈が困難な場合も多い。ここでは著者が従事してきた 音響による食品物性評価に関する研究の一端について 概説する。

2. 音速による果菜・根菜類柔組織の「かたさ」測定

\section{1 果菜・根菜類柔組織の弾性率}

果実の熟度は「かたさ」によって把握できることは 誰もが知る事実であり, 昔から収穫適期の判断や過熟

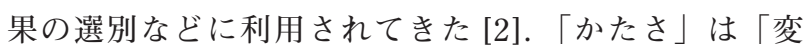
形に対する材料の抵抗 [3]」と定義されるが，変形様式 
により，ばね性のかたさ，引っかきに対する抵抗，堅 牢性など，さまざまな種類の「かたさ」がある.

Finney[4] は，音響共振法によって硬度 (firmness) が動的弾性率と相関があることを利用して硬さの評価 を行った。 その後, Abbotら [5], Cooke ら [6]も，農 産物の硬度の近似值として, みかけの弾性率を採用し ている．農産物の「かたさ」を把握するために弾性率 を計測することには一定の合理性と実績があると考え てよい.

等方弾性体中を $x_{1}-x_{2}-x_{3}$ 直交座標系の $x_{1}$ 方向に進む 波動を考えると，理論的には縦波と横波の 2 種類の音 速が存在する，等方弾性体の縦波音速 $C_{\mathrm{l}}$, 横波音速 $C_{\mathrm{S}}$ を, 古典的な弾性力学の弾性率 (体積弾性率 $K$, 剛性 率 $G$ ） と密度 $\rho$ を用いて整理すると次のようになる.

$$
\begin{gathered}
C_{1}=\sqrt{\frac{1}{\rho}\left(K+\frac{4}{3} G\right)} \\
C_{S}=\sqrt{\frac{G}{\rho}}
\end{gathered}
$$

式(1) と式 (2) を要約すると，波動による変形に関係 する弾性率を密度で除したものの平方根が音速に等し い.つまり，音速と密度を測定することができれば， 弾性率を推定することができる。農産物の密度は約 0.7 〜 $1.2 \mathrm{~kg} / \mathrm{m}^{3}$ の範囲に分布している [7] が，式(1)また は式 (2)の関係式の密度をこの範囲で振ってみると，音 速值は $30 \%$ 程度変化する。同一品種に限定すると，音 速の変化率はこれよりも小さくなり，約 $1 \sim 4 \%$ になる [8]. この密度の変化率が弾性率の変化率よりも小さい 場合には，振動伝播速度は弾性率に支配的に左右され， 弾性率が大きくなると振動伝播速度も大きくなる．杉 山によると，打音法によるメロンとナシの振動伝播速 度と見かけのヤング率の相関係数はそれぞれ 0.93[9] と 0.94[10] であった. 一方，Lu ら [11] がダイコンを用い て $50 \mathrm{kHz}$ の超音波の伝播速度とみかけのヤング率を計 測した結果，相関係数が 0.36 となり，相関がほとんど ないことが報告されている。同じような組織構造をも つ農産物でも結果が異なってくるのは，次節で述べる 組織内ガスの存在と振動モードの違いが関与している.

\section{2 組織内ガスが弾性率に及ぼす影響}

果菜類の果肉や根菜類の塊茎・塊根などの可食部は 細胞壁の薄い多面体の柔細胞 [12] が集合したもので一 般に柔組織とよばれる。 Fig. 1 にダイコン柔組織の光学 顕微鏡像 [13] を示す．液胞が細胞構造の大部分を占め ている。細胞間には細胞間隙（intercellular space）と よばれる空隙があり (画像の黒い部分), 水蒸気, 酸素, 二酸化炭素, 窒素などのガス体と少量の液相の水が存 在する．果菜類柔組織の硬さを担っているものは，細 胞壁の力学的強度と柔細胞の膨圧であると考えられる. 柔組織の体積・質量基準で最大の成分である水と, 組

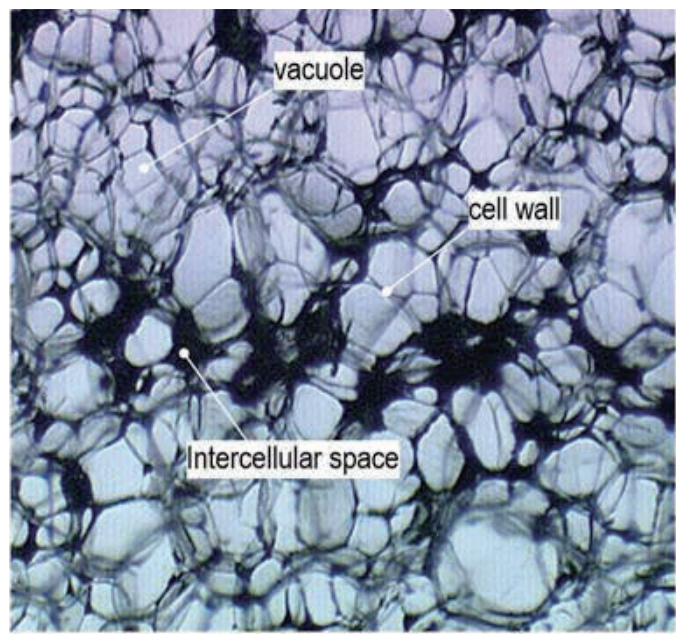

Fig. 1 Parenchyma tissue of a Japanese radish.

織内ガスの基本的な物理特性は大きく異なる. 水・ガ スともに流体であり，ヤング率あるいは剛性率は定義 できない，水は柔細胞の膨圧を担う媒質であり，また ガスの存在するボイドは柔組織の硬さを担う材料が久 損した箇所であることから，いずれも柔組織の全体の みかけ弾性率に何らかの影響があることが推察される.

Fig. 2 に示すように, 柔組織が細胞壁に相当する柔軟 な膜に囲まれた小さなコンパートメントで仕切られた 空間に水やガスが充填されて寄り集まった構造を取る ものとする．全コンパートメントに非圧縮性である水 が充填されていると，系全体に負荷される圧縮または 引っ張り力による体積変化がほとんど生じないために, 系全体の歪は膜強度と膨圧から決まるみかけの弾性的 特性に依存することになる，ところが圧縮性を有する ガスが充填されているコンパートメントが存在すると， 圧縮・引っ張りに対して体積変化が生じるために，系 全体の歪が大きくなり, みかけの弾性率は低下する. 気泡が多い食材が柔らかくなるのはこのためである. 全コンパートメントに水が充填されている系を巨視的 に均一な系とみなし，この系にガスが分散していると 考えたモデルが同図の気泡分散モデルとなる。これは 食品ゲルモデルとしてこれまでよく扱われてきたもの になるが，分散相のガス体がみかけの弾性率に及ぼす 影響はコンパートメントモデルの考え方とまったく同 じである [13].

この気泡分散モデルの気泡含有率と弾性率との関係 は, 岡野の線形粘弾性体の分散系に関する理論式 [14] をもとに，矢野らによってまとめられている [15]，さ らに, 著者は, 岡野が設定した分散系の仮定 [14] のもと, 簡単のために非散逸系とし複素弾性率を正の実数と考 えて， $G, K$, 及かけのポアソン比 $v$, 及かけのヤング 率 $E$ を整理した $[13,16]$ (式の詳細は省略).

これら分散系の式は連続相の物性と気泡の体積分率 中を変数としてみかけの弾性率を記述したものである. 


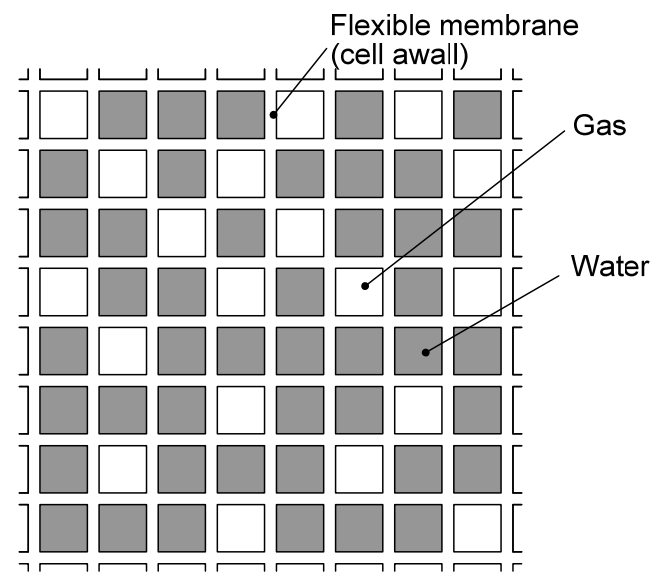

(a) Compartment model

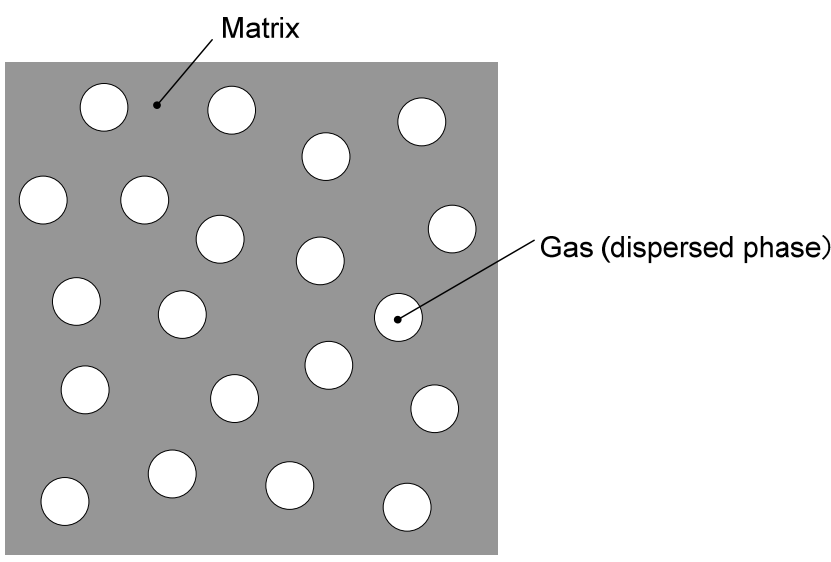

(b) Bubble-dispersion model

Fig. 2 Parenchyma-tissue models.

柔組織を考えた場合，連続相は細胞間隙を除く細胞実 質部にあたる。この細胞実質部の $80 \%$ 以上が水分であ

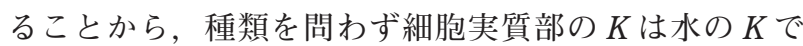
ある $2.22 \mathrm{GPa} に$ 近い值をとると考えられる。また，そ の $v$ も主成分の水が非圧縮性に近いために，0.5に極め て近い值をとると考えられる（註：完全な非圧縮性は 体積弾性率が無限大でない限りあり得ない). ここで, $K$ と $v$ は水のそれに近い值をとるものの，細胞実質部 は流体ではないということに注意が必要である。流体

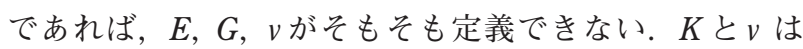
水のあくまで体積変化に着目した近似であり，このこ とは水であるということを示すものではない， $E, G$ は 果菜・根菜類の種類や個体によって異なるが，それは $K$, $v$ に当然反映される.

細胞実質部（連続相）の体積弾性率 $K_{1}$ （連続相の添 え字を 1 とする. 以下，同じ.）を水の体積弾性率 2.22 $\mathrm{GPa}$ ，ポアソン比を 0.499 として，みかけの $K, E, G$ それぞれと $\phi$ 関係を理論式から計算した（Fig. 3)
[13]. $K$ は， $\phi$ が零のとき， $K_{1}$ に等しく，約 $2.3 \% （ \mathrm{v} /$ v）になると $K_{1}$ の 10 分の 1 , 約 $20 \%(\mathrm{v} / \mathrm{v})$ で 100 分 の 1 になる. また $K$ と同様に， $\phi$ が大きくなるほど, $E$ と $G$ はともに減少する傾向であったが，その減少率 はいずれも $K$ の減少率ほど大きくない。例えば， $\phi$ が $20 \%(\mathrm{v} / \mathrm{v})$ のとき，Eは $E_{1}$ の約 $32 \%, G$ は $G_{1}$ の約 $29 \%$ の減少であるが, $K$ の減少率 $(99 \%)$ よりも小さい. 体積弾性率はヤング率・剛性率よりも大きく，とくに ガス体積分率が小さいほどその差は大きい。ガス体積 分率が零の場合には体積弾性率はヤング率の約 166 倍 の大きさがあるが，ガス体積分率が増すにつれてその 差は縮まり，20\% （v/v）で約 2.5 倍の大きさとなる.

Fig. 4 に, カボチャ (品種名：えびす南瓜), ダイコ ン (青首), サツマイモ (なると金時), ナシ (二十世紀), リンゴ (ラリタン), トゥガン (なんぶ琉球), スイカ (富 士光), ニンジン (品種不明), バレイショ (男爵薯) のみかけのヤング率と組織内ガス体積分率との関係 [8] を示す。全試料でみた場合，組織内ガス体積分率が大

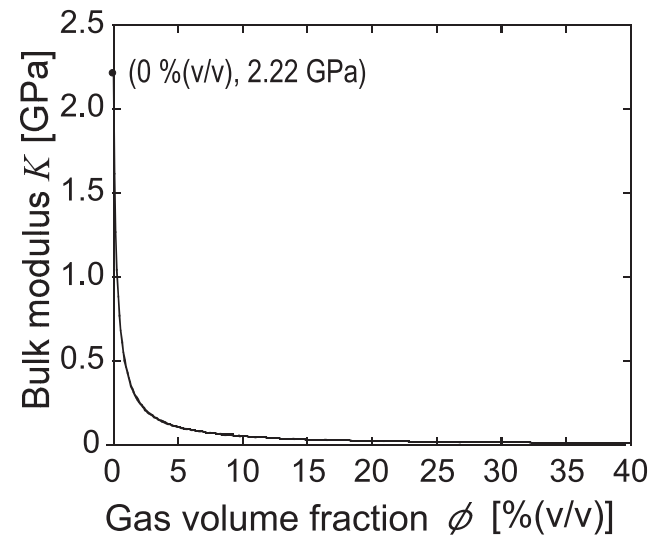

(a)

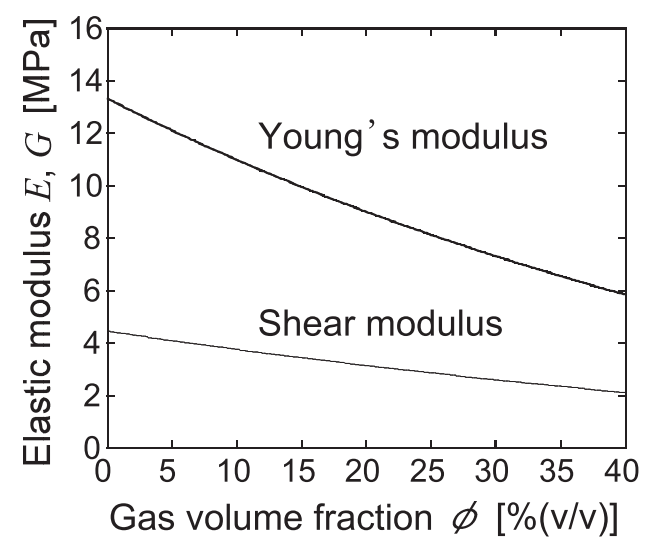

(b)

Fig. 3 Dependences of gas volume fraction on bulk modulus, Young's modulus and shear modulus. 


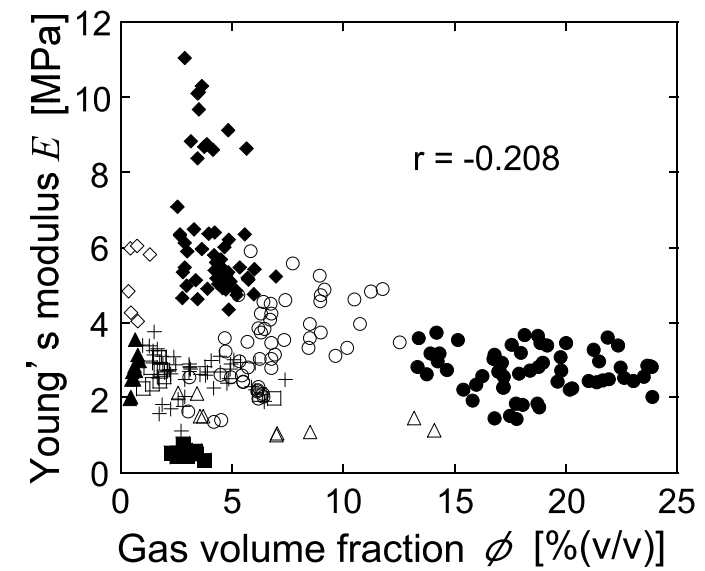

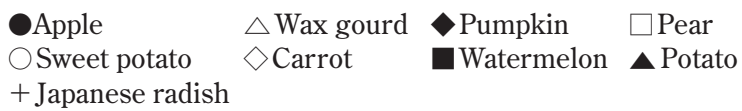

Fig. 4 Relations between gas volume fractions and Young's moduli for fruits and vegetables.

きくなるとヤング率は小さくなる傾向（相関係数 $\mathrm{r}=$ -0.208）にある。しかし極めて弱い相関であり，また 同一種でみた場合，有意な相関はみられなかった。こ のことは，細胞実質部の弾性率が一定であるという分 散系理論に打ける前提が成り立たないことに起因する ことを示唆している。

\section{3 組織内ガスが音速による「かたさ」評価に及ぼす 影響}

2.1 節で述べたように, メロンとナシでは振動伝播速 度とみかけのヤング率には高い相関があるものの，ダ イコンの場合には相関がないと報告されている，著者 の追試でも同じ結果が得られている. Fig. 5 にバイモル フ型振動子を用いて果菜類柔組織を打撃した際の振動

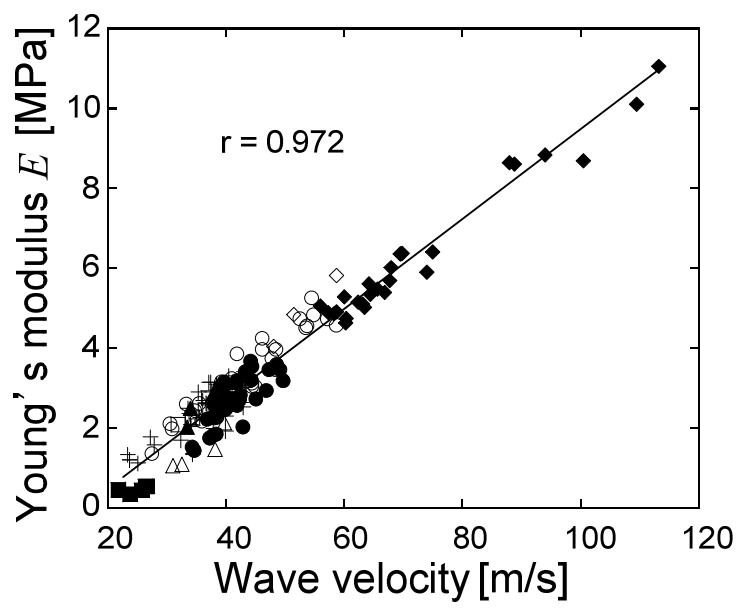

伝播速とみかけのヤング率との関係 [17] を示す．両者 には高い相関 $(r=0.97)$ がみられる。同じ柔組織を用 いて試料中の超音波縦波音速（周波数 $140 \mathrm{kHz}$ ）を測 定した結果，Fig. 6 に示すように， みかけのヤング率と の相関は低かった $(\mathrm{r}=0.36)$ [8].

打撃法（打音法）と超音波法との結果の違いは，測 定に用いた振動の周波数（振動数）の違いと弾性率に 対する組織内ガスの影響の違いに起因するものである. 打撃法では可聴域の振動となり，その振動による変位 は試料全体に及ぶ。このような有限媒体振動の伝播速 度と弾性率には次の関係が成り立つ。

Wave velocity $\propto \sqrt{\frac{\text { Young' s modulus or shear modulus }}{\text { density }}}(3$

超音波の場合，その波長が試料の大きさに比して十 分に小さいため，その波動は試料内部をビーム状に伝 播していく，振動による変位は，進行方向に対して垂 直の方向に対しては零となる状態を強いられることに なる。このような無限媒体中の振動の伝播速度は式 (1) で表される. Fig. 3 に示されるように, 組織内ガスの存 在が体積弾性率に与える影響は，剛性率に対する影響 よりも大きい. 式(1)と 2.2 節で述べた気泡分散系の式 から無限媒体中の縱波振動伝播速度 $C_{1}$ は次式で表され る $[8]$.

$C_{l}=\sqrt{\frac{K_{1}}{\rho_{1}}\left[\frac{2\left(1-2 v_{1}\right)}{2\left(1-2 v_{1}\right)+\left(1+v_{1}\right) \phi}+\frac{2\left(7-5 v_{1}\right)\left(1-2 v_{1}\right)}{\left\{\left(7-5 v_{1}\right)+2\left(4-5 v_{1}\right) \phi\right\}\left(1+v_{1}\right)}\right]}$

柔組織中の超音波振動伝播速度と組織内ガス体積分 率データについて, 式(4)をモデル式として非線形最小 二乗法によってフィッティングした結果を Fig. 7[8]に 示す，理論曲線は実測結果をよく表し，振動の伝播速

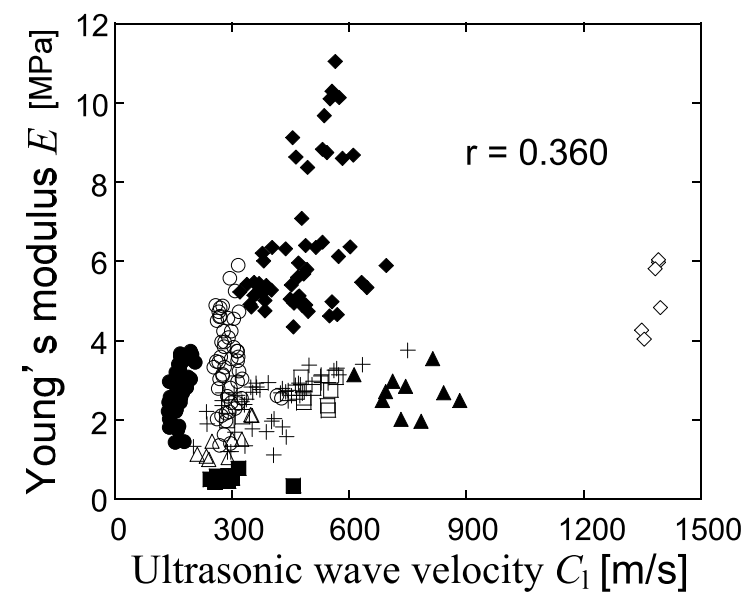

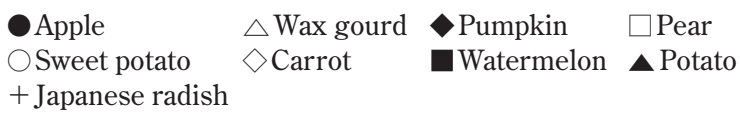

Fig. 5 Relation between wave velocities and Young's moduli for fruits and vegetables.

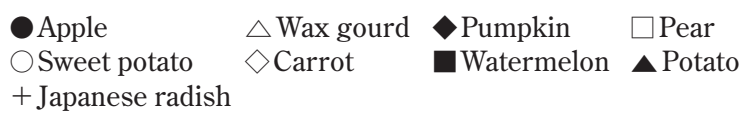

Fig. 6 Relation between ultrasonic wave velocities and Young's moduli for fruits and vegetables. 


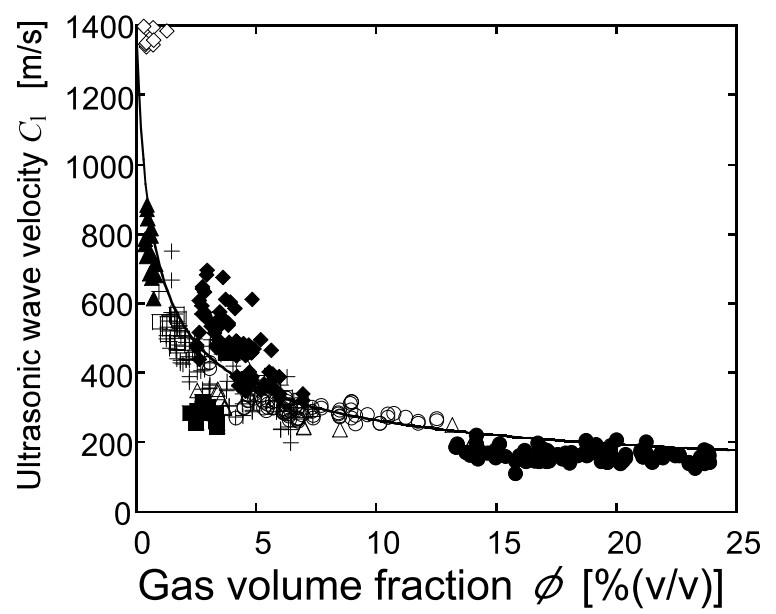

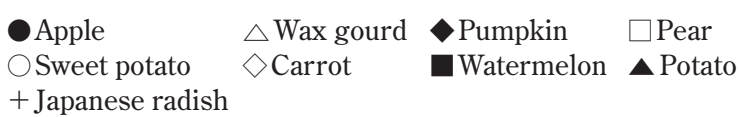

Fig. 7 Dependences of gas volume fractions on ultrasonic wave velocities for fruits and vegetables.

度のガス体積分率依存性は，体積弾性率のガス体積分 率依存性が支配的要因であることを示唆している。超 音波では，たとえヤング率または剛性率が同じでも， ガス体積分率が異なると伝播速度が異なってくること になる。これが振動伝播速度とみかけのヤング率の相 関が低い原因である。

以上から，果菜類・根菜類柔組織の体積弾性率はガ ス量に影響を受けやすく，超音波の音速は農産物の「か たさ」測定には利用できないと考えてよい，一方，柔 組織の「かたさ」との相関が高いヤング率や剛性率は, 組織内ガスの影響を体積分率ほど受けない。このため 打音法で得られる音速（振動伝播速度）は，果菜類・ 根菜類柔組織の「かたさ」測定の結果と高い相関をも つと考えられる.ここでは果菜類・根菜類柔組織の結 果について述べてきたが，その他の高含水率食品にも 拡張して考えることができ，例えば，超音波法では， 気泡率が数％程度であれば，その音速から気泡率，あ るいは密度の推定に利用可能である。また食品の「か たさ」は超音波法では測定することができないが，打 音法であれば測定可能である。

\section{3. 音響共鳴法による食品物性の非破壊実時間測定}

\section{1 ヘルムホルツ共鳴による体積測定}

Fig. 8 に示すようなネック (neck tube) と空洞部を もつ壳形の容器の口を吹くとボーという音が鳴る。こ れはへルムホルツ共鳴とよばれる古くから知られる音 響共鳴現象である。この容器をへルムホルツ共鳴器と いう。ネックの口を吹くとネック部の空気の塊が空洞 部の空気ばねを圧縮したり膨張したりすることで，い わゆるばね一質量系の振動系となる。その空洞部での

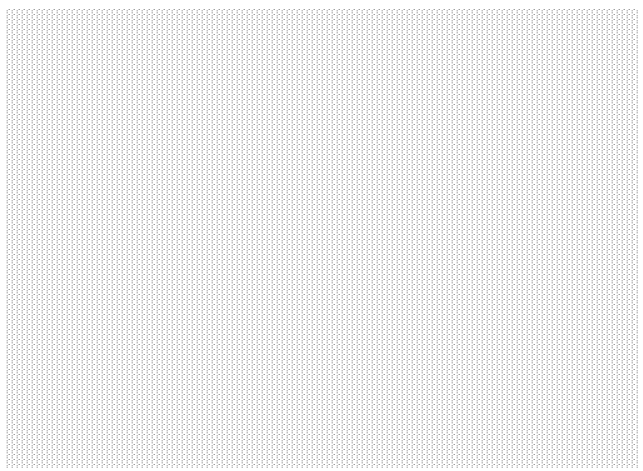

Fig. 8 Schematic diagram of a Helmholtz resonator.

振動エネルギーの一部がネック開口部から再放射され たものが共鳴音となって耳に聴こえる。このときの共 鳴周波数 $f$ は次式で表される.

$$
f=\frac{C}{2 \pi} \sqrt{\frac{1}{W-V} \frac{S}{l+l_{\mathrm{c}}}}
$$

ただし, 空気中の音速 $C$, 共鳴器空洞部体積 $W$, 内容 物体積 $V$, 共鳴器ネック長 $l$, 開口端補正量 $l_{\mathrm{c}}$ とする.

式 (5) は，共鳴器が同じであれば，共鳴周波数 $f$ は内 容物の体積 $V$ のの関数であることを示している。共 鳴器が空の状態のときの共鳴周波数を $f_{0}$ とすると, 式 (5)から次式が得られる.

$$
V=W \sqrt{1-\frac{f_{0}^{2}}{f^{2}}}
$$

共鳴器に物体を入れる前後で共鳴周波数を測定し, それぞれの周波数を式(6)に代入することで，その物体 の体積を求めることができる.

$f$ は，音波を共鳴器に入力したときの応答波形を周波 数解析することで決定する. 具体的には, 動電型スピー カーを共鳴器空洞部もしくはネックを挟んでもう 1 つ 設けた空洞部に接続し，スピーカーに共鳴周波数前後 の周波数成分をもつスウィープ信号を入力し，同時に ボイスコイルのインピーダンスを測定し，そのインピー ダンス波形からフーリエ変換を用いてそのパワースペ クトルを求める. スペクトル中のピーク周波数から $f$ を 決定する [18]. この方式で液体体積を推定した結果, 真体積との比較で決定係数は 0.999 以上，变動係数は 0.024 程度 [18] である。液体に限らず，気体を除いて 不定形の食品素材の体積を実用上で十分の精度で測定 できる。

食品工場での利用を考慮して，Fig. 9 (a)に示すよう にコンベアで移動中の食材の体積を連続的に測定可能 な装置を開発した [19]（註：この装置開発時には共鳴 音検出にマイクロホンを用いていた)。これはFig. 8 の 共鳴器の 1 本のネックを Fig. 9 (b) に示すように 3 本に 分ける。共鳴時には，ネック部の空気塊は同時に同方 向に変動するため，共鳴周波数は式 (5) に従う。その中 の 2 本を対向配置し，その 2 本のネックを貫通するよ 


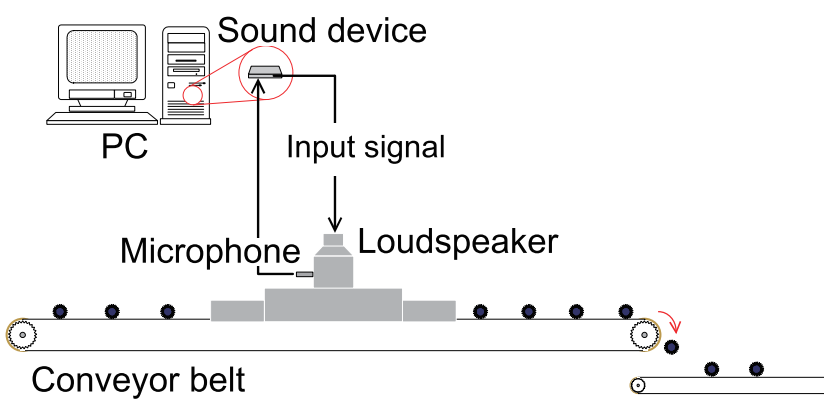

(a)

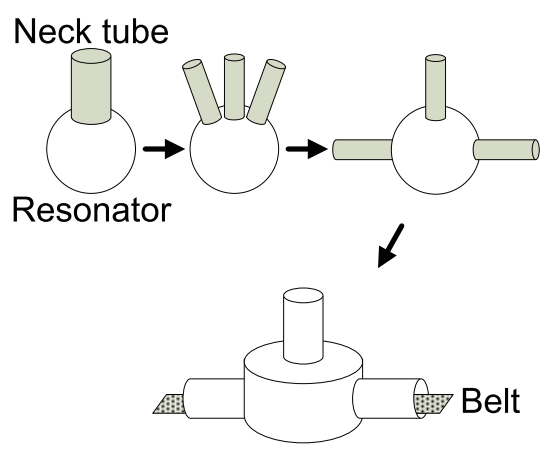

(b)

Fig. 9 Schematic diagram of a Helmholtz resonator with two openings (a) and a resonator with three neck tubes (b).

うにコンベアベルトを設置させたものは音響学的には まったく同一のものになる。Fig. 10 にこの装置を用い て金属棒を測定した結果を示すが，精度よく体積を測 定することができた [19]. また Fig. 11 に示すように， 市販卓上ミキサーに装着できる測定装置を開発し，ホ イップクリームやケーキ生地などのオーバーランや密 度をミキシング中に実時間測定することに成功した。 本件については，特許を取得するとともに，測定装置 と測定プログラムを複数の民間企業に販売し，現在も 販売中である.

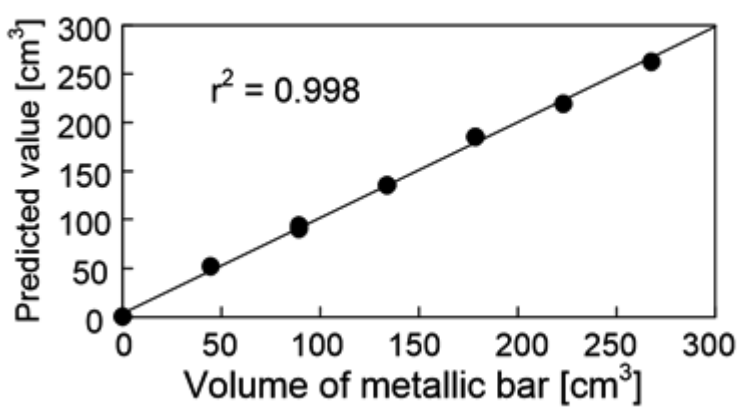

Fig. 10 Results of volume prediction for metallic bars by using the Helmholtz resonator with two openings shown in Fig. 9 (a).

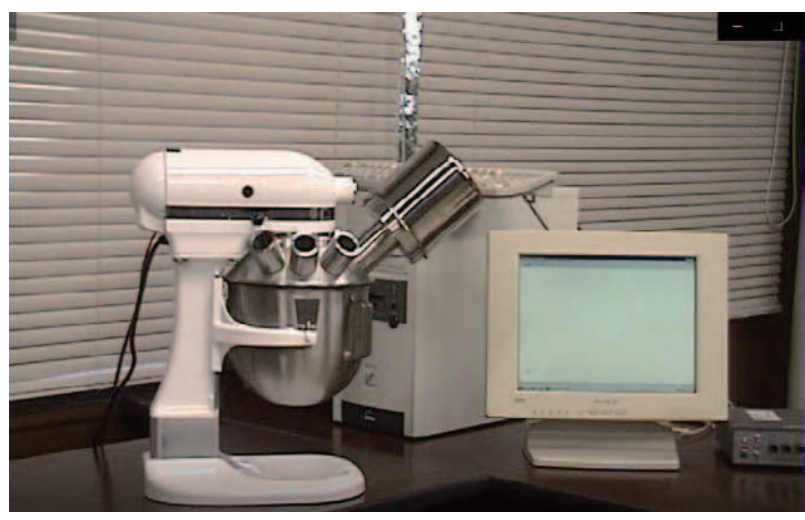

Fig. 11 Cake mixer equipped with Helmholtz resonance device.

\section{2 多孔質食品の共鳴周波数シフト現象とその利用可 能性}

生クリームのホイッピング中に Fig. 11 の装置で共鳴 周波数 $f$ を測定すると，泡を含むことによる体積増加に 伴い, $f$ も増加していく (Fig. 12). しかし，オーバー ランとは異なり，ホイップ開始直後からしばらくは $f$ が 減少していくフェーズが存在する (Fig. 12 の A が示す 部分).このフェーズでは，撹拌ワイヤーがクリーム液 面を激しく摇動させることで比較的大きい泡沫を液面 に作り出す。この低周波シフトについて考えてみる.

一般に，ばね一質量系で例えられるへルムホルツ共 鳴系では，ばねの振動が空洞部の空気の膨張・圧縮に 対応する. 共鳴時の周波数は数十から数百 $\mathrm{Hz}$ であるが, 圧縮時の温度増加，膨張時に温度減少に伴う共鳴器壁 を挟んだ系内外の熱の出入りが振動サイクルに追いつ かない，その結果，熱の出入りのない空洞部の空気の 膨張・圧縮変化は「断熱変化」として近似することが できる. Fig. 8 に示す共鳴器の空洞部空気の等価機械ス ティフネス (ばね定数に相当) $S_{\mathrm{eq}}$ は, 空気の比熱比を $\gamma$, 空気の圧力 (大気圧) を $P_{0}$ とすると, $S_{\mathrm{eq}}=\gamma P_{0} S^{2} W^{-1}$ と表され，またネック部の空気の等価機械質量 $M_{\mathrm{eq}}$ は, 空気密度を $\rho_{\mathrm{air}}$ とすると $M_{\mathrm{eq}}=\rho_{\mathrm{air}} S l$ と表される. 1 自 由度の機械振動系であるとすると，共鳴周波数は

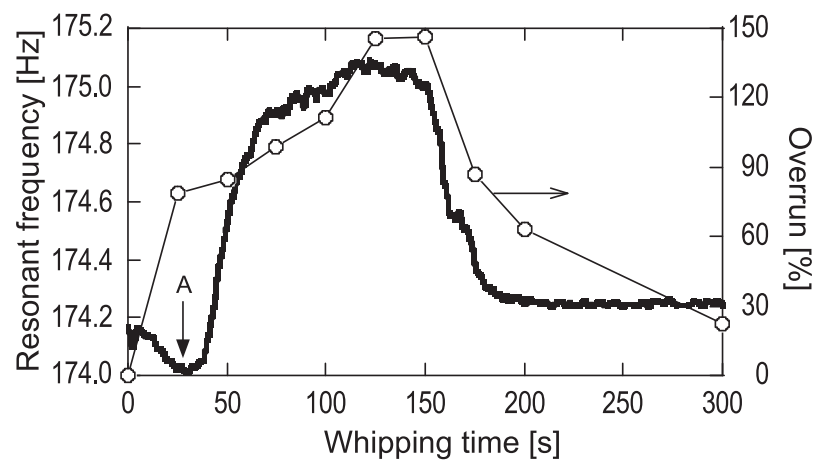

Fig. 12 Changes in resonant frequency and overrun of cream with whipping time; A shows "frequency drop". 
$f=(2 \pi)^{-1} S_{\mathrm{eq}}{ }^{0.5} M_{\mathrm{eq}}{ }^{-0.5}$ で表すことができる [18]. Fig. 8 の空洞内の試料表面に泡沫があると，スピーカーから の音が泡沫を膨張・圧縮させ, 気液界面を振動させるが, このサイクル運動に音エネルギーが消費される．空洞 部の空気側からみると，エネルギー散逸があることか ら，もはや断熱変化であるということができない。こ のエネルギー散逸は液面の面積や泡の特性によって異な るが, 熱力学でいう断熱変化と等温変化の間のポリト ロープ変化というべきである。一般に， $\gamma P_{0}$ は断熱体積 弾性率（この逆数が断熱圧縮率）を表すが，ポリトロー プ変化では，体積弾性率は $n P_{0}$ で表される， $n$ はポリト ロープ指数とよばれる. 理想気体では等温変化で $n=1$, 断熱変化で $n=\gamma$ となる. 空気の比熱比は 1.4 であるこ とから，泡沫がある場合には $n$ は 1 と 1.4 の中間の值を とる.つまり泡があることにより, 共鳴器空洞部の体積 弾性率が $n P_{0}\left(<\gamma P_{0}\right)$ となるため, スティフネスが小さ くなり共鳴周波数が減少すると考えられる.

泡沫による共鳴の低周波シフトは体積を過少評価す るという点から体積評価法としては問題がある。しか し，そのシフト量は泡沫による音響エネルギーによる ものであることから，泡沫の物性に関する情報を反映 しているものと考えられる。これを利用して，例えば ビールの泡の品質評価についての研究も現在進行中で ある [20]. 表面上に泡沫がのった構造のものだけでな く，内部に空隙を有する多孔質食品にまで対象をひろ げた場合でも，共鳴周波数は空隙に関連する何らかの 物性情報を有するものと考えられる。多孔質食品は連 続した相，マトリックスに気泡・空隙が空間的に分散 した構造を取る。気泡・空隙の構造から，独立した球 形に近い気泡が等方均一に分散した独立泡タイプと, 独立した空隙が少なく, 空隙同士が連通した連続泡タ イプに分類できる. 前者はホイップクリーム, はんぺん, そして加工途中の素材のメレンゲやケーキ生地といっ た食材で，ヘルムホルツ共鳴測定では泡が界面での振 動による音エネルギーの散逸から共鳴周波数の低下が みられる。この場合，音エネルギーの散逸量は，気泡 の量や界面の粘弾性が関与しているものと考えられる.

一方，パンやケーキスポンジのように後者の連続泡 タイプの多孔質材料を共鳴器空洞に入れず, Fig. 13 に 示すようにネックの上端を塞ぐように置いても，ネッ ク部は完全に閉塞されることがないため共鳴は生ずる. この場合の共鳴周波数は，ネック部が完全に開放され ているときの共鳴周波数よりも小さくなるが，著者は これも音エネルギーの散冕によるものであることを明 らかにした [21].

スピーカーを用いて空洞部空気が振動すると，ネッ ク部の空気の塊がネック端面からはみ出したり（Fig. $13(\mathrm{a}))$ ，引っ込んだりする (Fig. 13 (b))。このはみ出 し距離は開口端補正量として知られている。試料内部

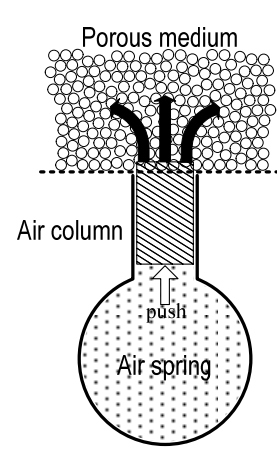

(a)

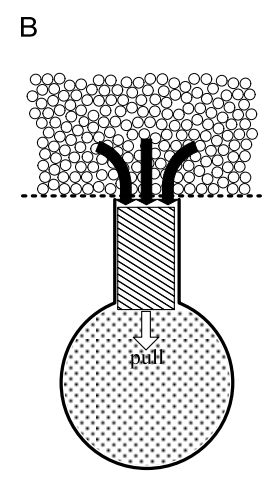

(b)

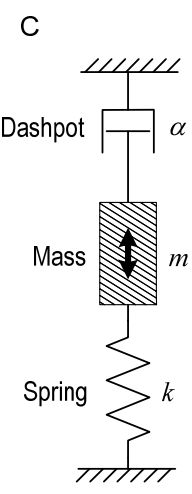

(c)
Fig. 13 Schematic of an open-type Helmholtz resonator whose tube mouth is covered by a porous medium $(a, b)$ and an equivalent model (c) [21].

の孔隙は連通しており，空気柱の動きに応じて孔隙中 で空気の流れが生ずる。その際，この流れは摩擦抵抗 を受ける. 粒体層中を通気させたときの抵抗 (圧力損失) と本質的に等価であると考えられる。そのため，この 音響振動系は, Fig. 13 (c) に示すように, 抵抗としてダッ シュポットを直列に入れたものが，等価機械振動系と なる.

ダッシュポットの流体がニュートン流体か，あるい は非ニュートン流体かについては，主として孔隙中の 気流の速度と孔隙の大きさによる影響を考慮する必要 がある．粗密波である音波によって発生する空気の動 きの線速度は，音波の粒子速度に相当すると考えると $5.0 \times 10^{4} \mathrm{~m} / \mathrm{s}$ となる（ただし，測定時の音の音圧を 0.2 $\mathrm{Pa}$, 空気密度 $\rho_{\text {air }}$ を $1.184 \mathrm{~kg} / \mathrm{m}^{3}$, 空気中の音速 $C$ を $340 \mathrm{~m} / \mathrm{s}$ とした場合)。例えば，穀粒堆積層の孔隙の大 きさなどのデータから算出した Re 数は 1 よりも小さい ため，孔隙中の気流は層流であると考えられる。この 場合，気流の線速度に比例する抵抗が生ずるニュート ン流体のダッシュポットと考えてよい.

孔隙が細く，サイズが小さいほど抵抗が大きく，ダッ シュポットの減衰係数が大きくなる．この等価振動系 から，共鳴周波数と減衰係数の関係は次式のように導 出できる.

$$
f_{d}=\frac{C}{2 \pi} \sqrt{\frac{1}{V} \cdot \frac{S}{l+l_{\mathrm{c}}}} \times \sqrt{1-A \times \alpha^{2}}
$$

ここで, $A=V\left(4 \rho l \gamma P_{0} C^{3}\right)^{-1}, \alpha$ は減衰係数を表す。 こ の式から，堆積層の厚さが一定の場合，減衰係数が大 きくなるほど，つまり抵抗が大きくなるほど周波数が 減少する.

直径 1，2，3，5，7 mm のガラスビーズ，大豆，小豆， 玄米，コーンを用いて，堆積層の厚みを変えながら共 鳴周波数を計測するとともに，試料を充填した試料容 器を通気用パイプに取り付けて, 流速 $0.04 \mathrm{~m} / \mathrm{s}$ の乾燥 窒素を流し, 充填層前後での圧力損失を計測した。流 
れ抵抗係数と共鳴周波数は式 (7)をモデル式とした近似 によく適合し，抵抗が増加するにつれて共鳴周波数が 減少する傾向がみられ，また粒体の種類の影響がみら れない。このことから，共鳴周波数から，通気抵抗と 関連のある空隙情報を得ることができるものと考えら れる [21].ここでは粒体層の例を示したが，連通した 孔隙構造をもつパンやスポンジでは，気泡が細かい内 相ほどその共鳴周波数は高くなった。 パンを対象に本 法を用いて共鳴測定を行うことで，切断することなく 内相のきめを評価できる可能性を示した.

\section{4. 超音波による食品成分や物性変化の非破壞実時間 測定法の開発}

超音波の非線形伝播現象に着目し，非線形パラメー タが生乳中の乳脂肪率と高い相関を示すことを見出し た [22].さらに，発酵や酵素によるミルクカード形成 過程で超音波位相速度が増加すること, そして位相速 度変化はカゼインの凝集に伴う圧縮率打よび密度変化 が支配的要因であることを明らかにした [23].また， 食品の冷凍による水結晶の生成や, 食用油の低温下で の結晶化過程での超音波位相速度測定により, 水結晶 化率の推定や油脂結晶化速度の定量化に有効なことを 明らかにした [24]. 食品のゲル化や涷結のような相変 化を伴う物性変化を, 超音波の群速度を用いてモニタ リングした研究事例はこれまでも報告されてきたが, 周波数分散性が大きい媒質では, 厹の群速度は系のサ イズや形状に大きく依存することから，モニタリング について実用的な利用を考えると難があった。位相速 度の利用は，周波数依存性を排除し，系に依存しない 食品物性測定法として有効であると考える。

\section{5. 咀嚼音と食感の関係に関する研究}

天ぷら，コロッケ，クッキーなどではサクサク感と よばれる食感が重視される。この食感は咀嚼時に食片 に破砕されるときに発生する振動をヒトが感知して得 られる感覚である。本研究では, ヒトの感覚器への「入 力」としての振動を, 定量的に把握する方法について 検討を行った。この定量化は, 食感と咀嚼音の関係を 検討するうえで必要となってくる。これまでは録音し た破砕音を周波数解析し, 周波数領域のパラメータを 決定することで定量化する報告例が多かったが，本研 究では, 時間領域での解析を行い, 破砕振動が小さな クラック振動の集合体であること，そしてそのクラッ ク振動の発生頻度がサクサク感の官能評価結果と高い 相関があることを実証した。本測定法と解析法は特許 登録され，測定装置として開発済みである [25].

\section{6. おわりに}

本稿では音をツールとして食品の物性を捉える方法 について紹介した。音と食品は一見突飛な組み合わせ のように思えるが，音という現象は粘弾性論としっか り結びついているため, 音をッールとして食品のテク スチャー情報を得ようとする発想はそう突飛なもので はない，そもそも，そうした理論を学ばなくとも，我々 は経験的にスイカをたたいて空洞の有無や食べ頃を判 断してきたのである. それ以外の場面でも, 調理の過程, 例えば，まな板で野菜を切るとき，鍋で煮るとき，油 で揚げるとき，フライパンで焼くときに発せられる音 を調理のたびに聞いて打り，時にはその音の変化で出 来具合を判断したりしている，契食時にも，ピザを切 り分けるときにザクザクとした音や, 新鮮な野菜を咀 嚼するときのパリパリという音を聞き，そして天ぷら やコロッケのサクサク感などを振動として感知してい る. 加工から喫食するまでの各場面に打いて食品は非 常に「打しゃべり」なのである。このとき食品が何をしゃ ベっているのかがわかれば，午のうちのいくらかから 食品の品質向上に有用な情報を引き出すことが期待で きる、その言葉の意味を知ることが，音と食品に関す る研究の今後の重要な課題となろう.

\section{謝辞}

音響による食品物性評価の研究は，筆者が修士研究 のテーマとして取り組んで以来，京都大学抢よび岐皁 大学に打いて発展的に継続してきたものである。この 間, 諸先生方にご指導いただくとともに, 多くの学生 の皆様に研究にご協力賜りました。ここの深く感謝を 申し上げます。

\section{NOMENCLATURE}

$C$ : sound velocity in air, $\mathrm{m} / \mathrm{s}$

$C_{1}:$ longitudinal wave velocity, $\mathrm{m} \cdot \mathrm{s}^{-1}$

$C_{\mathrm{S}}$ : transverse wave velocity, $\mathrm{m} \cdot \mathrm{s}^{-1}$

$E$ : Young' s modulus, $\mathrm{Pa}$

$f$ : Helmholtz resonant frequency, $\mathrm{Hz}$

$f_{0}$ : resonant frequency of empty resonator, $\mathrm{Hz}$

$G$ : shear modulus, $\mathrm{Pa}$

$K$ : bulk modulus, $\mathrm{Pa}$

$l$ : length of neck tube, $\mathrm{m}$

$l_{\mathrm{C}}$ : open end correction of neck tube, $\mathrm{m}$

$M_{\text {eq }}$ : equivalent mass of resonator-cavity, $\mathrm{kg}$

$P_{0}$ : pressure of ambient air, $\mathrm{Pa}$

$S$ : cross-sectional area of neck tube, $\mathrm{m}^{2}$

$S_{\text {eq }}$ : equivalent stiffness of resonator-cavity, $\mathrm{N} \cdot \mathrm{m}^{-1}$ 
$V$ : volume of sample in resonator-cavity, $\mathrm{m}^{3}$

$W$ : volume of resonator-cavity, $\mathrm{m}^{3}$

$\alpha$ : damping coefficient of dashpot, $\mathrm{Ns} / \mathrm{m}$

$\gamma$ : specific heat ratio of ambient air, -

$v$ : Poisson' s ratio, -

$\rho \quad$ : density, $\mathrm{kg} \cdot \mathrm{m}^{-3}$

$\rho_{\text {air }}$ : density of air, $\mathrm{kg} \cdot \mathrm{m}^{-3}$

$\phi \quad$ : gas volume fraction, -

suffix

1: continuous phase

2: dispersed phase

\section{References}

1) T. Nishizu; "Development and application of acoustic methods for characterizing physical properties of food products" (in Japanese). Proc. of the 20th Annu. Meeting of Jap. Soc. Food Eng, (2019).

2) J. Sugiyama, T. Katsurai, J. Hong, H. Koyama, K. Mikuriya; Melon ripness monitoring by a portable firmness tester. Trans. of ASAE, 41, 121-127 (1998).

3) The Society of Polymer Scinece, Japan; "Handbook for Highpolymer Materials (Koubunshi Zairyou Binran”, Corona publishing, Tokyo, Japan, 1973, p. 335.

4) E. E. Finney; Dynamic elastic properties of some fruits during growth and development. J. Agr. Eng. Res., 12, 249-256 (1967).

5) J. A. Abbott, G. S. Bachman, R. F. Childers, J. F. Fitzgerald, F. J. Matusik; Sonic techniques for measuring texture of fruits and vegetables. Food Tech., 22, 635-646 (1968).

6) J. R. Cooke, R. H. Rand; A mathematical study of resonance in intact fruits and vegetables using a 3-media elastic sphere model. J. Agr. Eng. Res., 18, 141-157 (1973).

7) N. N. Mohsenin; "Physical properties of plant and animal material (Shokuhin no Bussei)", Korin, Tokyo, Japan, 1982, p.632.

8) T. Nishizu, Y. Ikeda; "Studies on measuring qualities of fruits and vegetables by acoustic technique (part2)” (in Japanese). J. JSAM, 63, 74-83 (2001).

9) J. Sugiyama, T. Katsurai, J. Hong, H. Koyama, K. Mikuriya; Melon ripeness monitoring by a portable firmness tester. Trans. ASAE, 41, 121-127 (1998).

10) J. Sugiyama; Application of non-destructive portable firmness tester to pears. Food Sci. Technol. Res., 7, 161-163 (2001).

11) F. Lu, G. Shau, F. Chung; Ultrasonic properties of radish under chilling storage, Proc. Intl. Symp. on Agricultural Mechanization and Automation 97, 2, 263-268 (1997).
12) R. Taguchi; "Synopsis plant physiology: basics and applications (Shokubutsu seirigaku taiyou : kiso to ouyou)", Yokendo, Tokyo, Japan, 1998, p.27.

13) T. Nishizu, Y. Ikeda; "Studies on measuring qualities of fruits and vegetables by acoustic technique (part1)" (in Japanese). J. JSAM, 62, 51-59 (2000).

14) K. Okano; "Viscoelastic properties of disperse systems (Bunsankei no mikake no nendansei teisuu)" (in Japanese). Oyo Buturi, 36, 1003 - 1007 (1967).

15) T. Yano, S. Matsumoto, H. Hayashi, M. Kako; "Basic lectures in food engineering 9: Emulsification and dispersion (Nyuuka to bunsan)”, Korin, Tokyo, Japan, 1988, p. 105.

16) T. Nishizu; "Mechanical properties of parenchyma tissue of fruits and vegetables" (in Japanese). Proce. the 24th Symp. on Food Hydrocolloids, (2013).

17) T. Nishizu, Y. Ikeda; "Studies on measuring qualities of fruits and vegetables by acoustic technique (part3)" (in Japanese). J. JSAM, 63, 53-61 (2001).

18) T. Nishizu, Y. Torikata, T. Yamashita, T. Sakamoto, Y. Futaya, A. Nakano; "Determining liquid volume by using Helmholtz resonance - measurement method based on electrical impedance of loudspeaker -” (in Japanese). J. Jpn. Soc. Microgravity Appl, 22, 121-127 (2005).

19) T. Nishizu, Y. Ikeda, Y. Torikata, S. Manmoto, T. Umehara, T. Mizukami; Automatic, continuous food volume measurement with a Helmholtz resonator. CIGR J., 3, FP 01004 (2001).

20) Y. Ueda, T. Nishizu, N. Katsuno, A. Isoe, K. Hatanaka; "Studies on quality evaluation for beer foam using the phenomena of Helmholtz resonance" (in Japanese). Proc. JSBBA 2018, (2018).

21) T. Nishizu, E. Tomatsu, N. Katsuno; Airflow resistance measurement for a layer of granular material based on the Helmholtz resonance phenomenon, Biosci. Biotechnol. Biochem. 81, 823-830 (2017).

22) T. Nishizu; "Studies on monitoring of sol-gel transition for milk protein solution by using non-linear parameter of ultrasonic wave" (in Japanese). Annu. report of Nestlé Science Promotion Committee, 2, 35-43 (1995).

23) T. Nishizu, E. Isaji, K. Takatsu, S. Okabe, S. Kawabata, K. Goto; Influence of changes in $\mathrm{pH}$ during milk coagulation process on ultrasonic phase velocities of milk, iCEF11 Congress Proc., MCF566, 1-5 (2011).

24) T. Sugiyama, T. Nishizu, K. Goto, Xinjile, N. Kondo, H. Shimizu; Monitoring of food freezing process by using ultrasonic method, Proc. the 5th CIGR Section VI Intl. Symp. on Food Processing, Monitoring Technology in Bioprocess and Food Quality Management, 137-142 (2009).

25) T. Nishizu; "Crispy, Crunchy, and Crackly Sounds Emission 
during Biting or Chewing Foods" (in Japanese). J. Cookery Science Japan, 50, 127-132 (2017).

要

旨

超音波音速を測定することで，乳酸発酵過程のミル クカード強度の時間変化や, 食品モデルの冷凍過程に おける凍結率変化のモニタリングが可能であることを 見出した。一方，青果物の超音波音速は，組織の「か たさ」ではなく，組織内ガス体積分率支配であるが， 周波数の低い打撃振動の伝播速度は，「かたさ」を表す
弾性率と高い相関を示すことを明らかにした。また， ヘルムホルツ音響共鳴現象を利用した食品の体積や密 度の測定装置を開発した。 そして食品中の空隙の存在 が，共鳴周波数の低周波シフトをもたらすことを見出 すとともに，空隙がもたらす物性と共鳴周波数の関係 に関する理論的考察を行い，ビールの泡の特性やパン のきめ評価への利用を提案した。ささらに，油ちょう食 品の咀嚼中に生ずるクラック振動の発生頻度がサクサ ク感の官能評価結果と高い相関にあることを明らかに した. 